\author{
Ranjana Yadav and Deepak Srivastava
}

\title{
STUDIES ON CARDANOL-BASED EPOXIDIZED NOVOLAC RESIN AND ITS BLENDS
}

\author{
Department of Plastic Technology, H. B. Technological Institute \\ Kanpur - 208002 (U.P.), India, \\ dsri92@gmail.com
}

Received: May 05, 2008

\begin{abstract}
Cardanol-based novolac-type phenolic resin was synthesized with a mole ratio 1.0:0.5 of cardanol-toformaldehyde using a dicarboxylic acid catalyst such as succinic acid. The cardanol-based novolac-type phenolic resin may further be modified by epoxidation with epichlorohydrin excess at $393 \mathrm{~K}$ in a basic medium to duplicate the performance of such phenolic-type novolacs. Carboxyl-terminated butadiene acrylonitrile copolymer (CTBN) has been studied by various researches with diglycidyl ether of bisphenol-A (DEGBA) epoxy resin and epoxidized phenolic novolac resins. The epoxidized novolac resin was blended with different weight ratios of carboxyl-terminated butadiene acrylonitrile copolymer (CTBN) and cured with a stoichiometric amount of polyamine curing agent. The formation of various products during the synthesis of cardanol-based novolac resin, epoxodized novolac resin and blending of epoxidized novolac resin with CTBN has been studied by Fouriertransform infrared (FTIR) spectroscopic analysis. Further, the products were confirmed by a proton nuclear magnetic resonance ( $\left.{ }^{1} \mathrm{H}-\mathrm{NMR}\right)$ spectroscopic analysis. The number average molecular weight was determined by a gel permeation chromatography (GPC) analysis. The blend sample, having $15 \mathrm{wt} \%$ CTBN concentration showed minimum cure time and most thermally stable systems.
\end{abstract}

Key words: cardanol, formaldehyde, novolac, epichlorohydrin, epoxy resin, butadiene acrylonitrile copolymer, spectral methods.

\section{Introduction}

Cashew Nut Shell Liquid (CNSL), an agricultural renewable resource and the byproduct of the cashew industry, holds a considerable promise in the different directions because it is the source of unsaturated hydrocarbon phenol, an excellent monomer for thermosetting polymers production. Vacuum distillation of CNSL yields a pure cardanol. Cardanol is $n$-pentadecadienyl phenol, the aliphatic side chain usually consists of mixture of one, two and three double bonds in a linear chain with a saturated side chain. CNSL and cardanol are used in the manufacture of special phenol resins for coatings, lamination and as friction materials. These polymers are synthesized from CNSL or cardanol either by polycondensation with electrophylic compounds such as formaldehyde, furfuraldehyde or by chain polymerization through unsaturation presented in the side chain using an acid and base catalyst. The cardanol based novolac type phenolic resins may further be modified by epoxidation with epichlorohydrin to duplicate the performance of such phenolic type novolacs [1-4]. Having several outstanding characteristics, epoxy resins show low impact resistance in their cured state which limits the applications of epoxy resins. To alleviate this deficiency, epoxy resins are modified by the incorporation of a reactive liquid rubber without a significant loss in other properties [5-9]. In this way, a carboxyl-terminated copolymer of butadiene and acrylonitrile (CTBN) has been used by various researches [10-13] with diglycidyl ether of bisphenol-A (DGEBA) epoxy resin and epoxidized phenolic novolac resins. But, carboxyl-terminated polybutadiene (CTBN) is nowhere used with cardanol based epoxy resins. Therefore, we have tried to produce the modified epoxy matrices, based on cardanol, by physical blending with CTBN and we have studied the effect of CTBN addition on thermal and morphological changes in the blends.

\section{Experimental}

\subsection{Materials}

Cardanol (M/s Satya Cashsew Pvt. Ltd., Chennai), formaldehyde ( $40 \%$ solution), succinic acid, sodium hydroxide, epichlorohydrin (All from M/s Thomas Baker Chemicals Ltd., Mumbai), polyamine (M/s Ciba Specialty Chemicals Ltd., Mumbai) with amine value 1240$1400 \mathrm{mgKOH} / \mathrm{g}$ and carboxyl-terminated butadiene acrylonitrile copolymer (CTBN) (Hycar 1300x13) were the initial reagents. CTBN was kindly supplied by $\mathrm{M} / \mathrm{s}$ Emerald Performance Materials, LLC, Hong Kong having molecular weight $M_{n}$ of 3500 and acrylonitrile and carboxyl contents 27 and 32 percent, respectively. 


\subsection{Synthesis of cardanol- based novolac- type phenolic resin}

Novolac resin with mole ratio 1:0.5 of cardanol $(C)$ to formaldehyde $(F)$ was prepared using bicarboxylic acid, viz., succinic acid, as a catalyst by a method similar to that adopted by Knop and Schieb [14] for a phenol based novolac. The catalyst (1\% based on cardanol) was, first, dissolved in methanol at $333 \mathrm{~K}$. Half of a catalyst solution was added to cardanol (about $30 \mathrm{~g}$ ), charged in a three-necked round bottom flask fitted with a Leibig's condenser and mechanical stirrer. The remaining half of the methanolic solution of the catalyst was added to the formaldehyde $(40 \%)$ and this was added to the cardanol dropwise within one hour, once the temperature of the reaction kettle was maintained at $393 \mathrm{~K}$. The initial $\mathrm{pH}$ of the reaction mixture was 6.0 reduced to a value of 4.8 after $5 \mathrm{~h}$ of reaction at $393 \mathrm{~K}$. Free-formaldehyde and free-phenol contents were checked after every $45 \mathrm{~min}$ to see the completion of the methylolation reaction [15]. The reaction product was cooled and dried under vacuum at $333 \mathrm{~K}$ overnight before purification by column chromatography. A resin solution prepared with $n$-hexane, charged to the silica gel column chromatographic purification, was adopted mainly to remove unreacted components, impurities etc., from the methylolated cardanol. Purification was effected using the elutent mixture of ethyl acetate - benzene (60:40). The purified resin was analyzed by infra-red (IR) spectroscopic, nuclear magnetic resonance $\left({ }^{1} \mathrm{H}-\mathrm{NMR}\right)$ spectroscopic, mass spectroscopic and gel permeation chromatographic (GPC) analysis.

\subsection{Epoxidation of cardanol-based novolac-type phenolic resin}

The cardanol-based novolac-type phenolic resin was epoxidized by a method similar to that given in [16]. Approximately 1.0 mole of a novolac resin was taken in a $500 \mathrm{ml}$ three-necked round-bottomed flask and 10 moles of epichlorohydrin were added to it while stirring. Then $40 \%$ sodium hydroxide solution was added dropwise to the above mixture for a period of $5 \mathrm{~h}$ at $393 \mathrm{~K}$. The reaction mixture was then subjected to distillation under vacuum for removal of unreacted epichlorohydrin. The resulting viscous product was stored for a further analysis.

\subsection{Preparation of blends of epoxidized novolac resin and carboxyl-terminated butadiene acrylonitrile copolymer (CTBN)}

The epoxy resin was mixed physically with varying concentration of CTBN ranging between $0-20 \mathrm{wt} \%$ with an interval of 5 wt \% (Table 1).

Sample designations

\begin{tabular}{|l|c|c|c|}
\hline \multicolumn{1}{|c|}{ No. } & Epoxy, wt $\%$ & $C T B N$, wt $\%$ & Sample code \\
\hline \multicolumn{3}{|c|}{ Cardanol-based epoxidized novolac resin (prepared from novolac resin $C F_{52}$ ) } \\
\hline 1. & 95 & 5 & $E C F_{521}$ \\
\hline 2. & 90 & 10 & $E C F_{522}$ \\
\hline 3. & 85 & 15 & $E C F_{523}$ \\
\hline 4. & 80 & 20 & $E C F_{524}$ \\
\hline
\end{tabular}

\subsection{Fourier-transform infra-red (FTIR) spectroscopic analysis and $\mathrm{N}$ uclear magnetic resonance ( $\left.{ }^{1} \mathrm{H}-\mathrm{N} M \mathrm{R}\right)$ spectroscopic analysis}

Fourier-transform infra-red (FTIR) spectra of the prepared samples were recorded on a Perkin-Elmer (Model 843) infra-red spectrophotometer, using $\mathrm{KBr}$ pellet, in the wave length range of $500-4000 \mathrm{~cm}^{-1}$. ${ }^{1} \mathrm{H}-\mathrm{NMR}$ spectra of cardanol-based novolac and epoxidized novolac resins were recorded on Bruker DRX - 300 NMR spectrophotometer in the temperature range of 183 to $353 \mathrm{~K}$.

\subsection{Gel permeation chromatographic (GPC) analysis and mass spectroscopic analysis}

Gel permeation chromatograph (GPC) (Instrument procured from E Merck consisting of a pump, L-7350 column oven and L-7490 R.I. Detector) was used for determination of the average number molecular weight of the synthesized cardanol-based novolac resin. A small quantity of the resin was dissolved in THF; which acted both as a mobile and stationary phase and was injected into the instrument. Mass spectra of the prepared samples were recorded on Micromass TofSpec2e MALDI TOF mass spectrophotometer.

\subsection{Differential scanning calorimetric (DSC) analysis}

Cure temperature of the prepared samples were measured by taking very little quantity of blend samples into a shallow aluminum pan sealed by an aluminum cover of differential scanning calorimetry (DSC) (TA, Instrument, USA; Model DSC Q20). It was placed in a sample cell of the instrument. The starting temperature, 
programmed rate and final temperature were taken at a heating rate of $283 \mathrm{~K} / \mathrm{min}$.

\subsection{Thermogravimetric analysis}

The thermal stability of the blend samples was determined by a comparison of the onset degradation temperature (up to $5 \%$ weight loss) of the cured samples with that of thermogravimetric analyzer (TGA) of TA Instruments (Model Q50 TGA) at a heating rate of $283 \mathrm{~K} / \mathrm{min}$ in the nitrogen atmosphere from ambient to $923 \mathrm{~K}$.

\subsection{Morphology}

The morphological changes due to addition of CTBN into the epoxy matrix were studied by JOEL scanning electron microscope (SEM) (Model JSM 5800). The rubber domains distributed in the matrix and interaction of these domains with the epoxy matrix specimen surface could be observed by SEM. For this, the fractured samples were coated with a thin layer of gold-palladium alloy by sputtering to provide conductive surfaces

\section{Results and Discussion}

\subsection{Synthesis of cardanol-formaldehyde novolac type phenolic resin}

The methylolation of cardanol was carried out with formaldehyde in the presence of dicarboxylic acid, viz., succinic acid. The initial $\mathrm{pH}$ of the reaction mixture found to be 6.0. The formylation reaction was carried out with 0.5 mole ratio of cardanol-to-formaldehyde. Therefore, under these experimental conditions the complete formylation might be expected to yield resin with a high ortho-ortho linkages for the phenolic novolac resin. The completion of the methylolation reaction was checked by

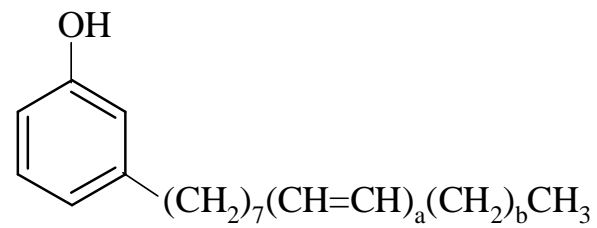

where, $\mathrm{a}=1 ; \mathrm{b}=5$

\section{Scheme 1}

periodic withdrawal of reaction mixture to analyze formaldehyde using hydroxylamine hydrochloride [17]. The final $\mathrm{pH}$ of the reaction mixture was found to be 4.8 . The decrease of $\mathrm{pH}$ in the methylolated cardanol might be ascribed to the formation of monohydroxyl substituted cardanol [18].

\subsection{FTIR and ${ }^{1} \mathrm{H}-\mathrm{N} M \mathrm{R}$ spectroscopic analysis of cardanol-based novolac-type phenolic resin}

Cardanol is a monoene meta-substituted phenol. On the basis of FTIR, NMR and mass spectroscopic analysis and gel permeation chromatography (GPC) analysis elucidated the structure of cardanol. Therefore, the empirical formula can be taken as $\mathrm{C}_{21} \mathrm{H}_{34} \mathrm{O}[19,20]$ and the structure of cardanol may be proposed as shown in Scheme 1.

A shift of the peak from 1075 to 1102 and appearance of the peak near $1708 \mathrm{~cm}^{-1}$ (Fig. 1) was observed in a methylolated cardanol due to the $\mathrm{C}=\mathrm{O}$ stretching from $\mathrm{CH}_{2} \mathrm{OH}$. It has also been found that the intensity of peaks at $1594 \mathrm{~cm}^{-1}(\mathrm{C}=\mathrm{C}, \mathrm{str}), 3009 \mathrm{~cm}^{-1}$ (C-H str of alkene) and $779 \mathrm{~cm}^{-1}(\mathrm{C}-\mathrm{H}$ out-of-plane deformation) remained almost unaffected which indicated that the polymerization has taken place through substitution of $\mathrm{CH}_{2} \mathrm{OH}$ and not through the double bonds in the side

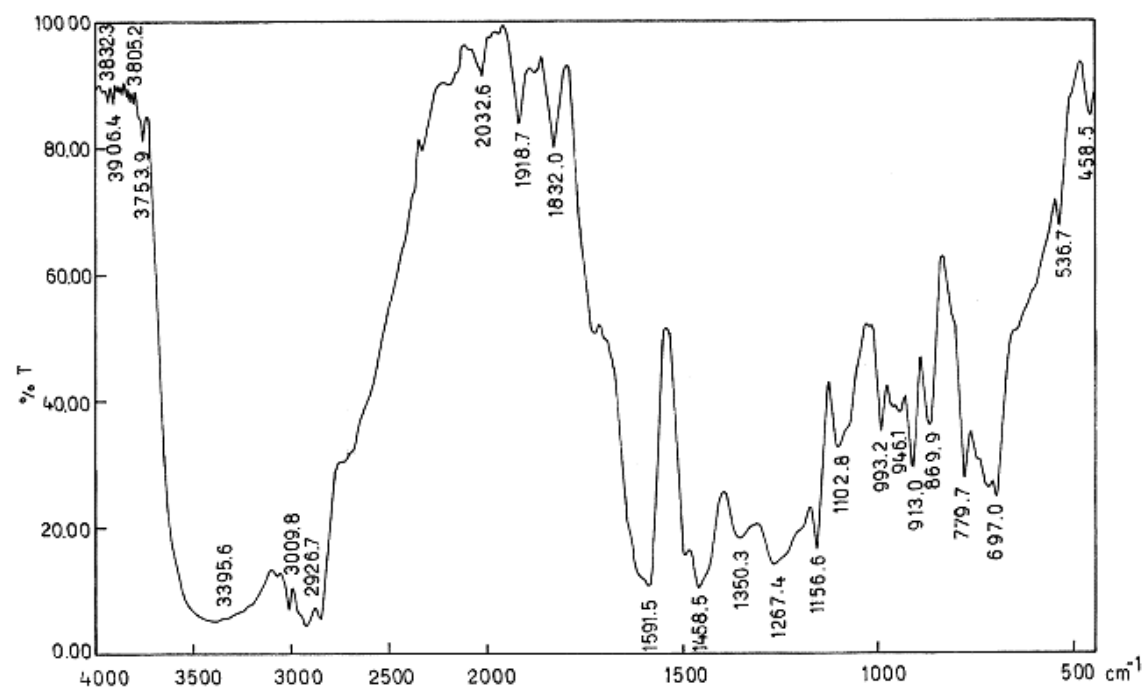

Fig. 1. FTIR spectrum of novolac resin $C F_{52}$ 


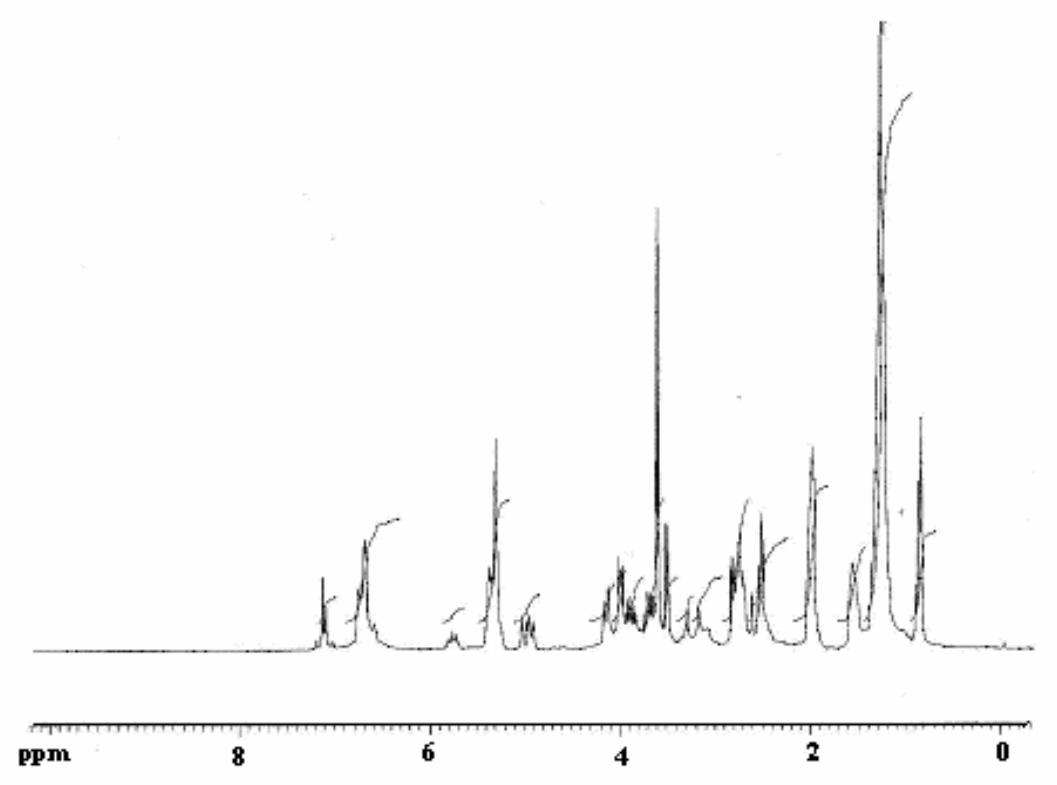

Fig. 2. ${ }^{1} \mathrm{H}-\mathrm{NMR}$ spectrum of novolac resin $C F_{52}$.

chain. The band at 3395 for the sample $C F_{52}$, may appear due to the presence of hydroxyl groups in the methylolated cardanol. Small peaks near 946 and $973 \mathrm{~cm}^{-1}$ indicated the substitution in benzene nuclei. The small peaks near 913 and $697 \mathrm{~cm}^{-1}$ might appear due to three adjacent hydrogen atoms in the benzene nuclei. The peak appearance near $722 \mathrm{~cm}^{-1}$ (Fig. 1) indicated the orthoand para-substitution in the benzene nuclei. The preceding spectral data were found to be identical with those given in literature [21, 22].

In the ${ }^{1} \mathrm{H}-\mathrm{NMR}$ spectra $C F_{52}$ (Fig. 2) novolac resin, the peak near 6.6-6.8 $\delta$ might appear due to the aryl protons of the benzene nuclei. The peaks around the region of 7.1$7.3 \delta$ appeared due to the phenolic hydroxyl in the novolac resin. The peak at $5.3 \delta$ might be attributed to the methylene protons whereas the peaks between $0.8-2.8 \delta$ appeared due to the presence of long alkyl aliphatic side-chain, originally observed in cardanol. The terminal methyl group of the alkyl side chain may also be seen as a small peak at $0.8 \delta$. The peak at $3.7 \delta$ indicated the presence of methylene protons of $\mathrm{C}_{6} \mathrm{H}_{5}-\mathrm{CH}_{2}-\mathrm{C}_{6} \mathrm{H}_{5}$ for the bridge between the phenyl rings [23]. All these spectral data indicated that the condensation of methyolated cardanol has been completed under experimental conditions and was fully consisted of the proposed structure (Scheme 6) resulting due to reaction mechanism shown in Schemes 2-5.

On the basis of the preceding discussions, the following reaction mechanism, similar to that proposed by Kuriakose and Manjooran [24], may be proposed. The mechanism of formation of novolac oligomers, in acidic media, using excess of cardanol over formaldehyde might proceed in four steps. First, a methylene glycol was protonated by an acid from the reaction medium, which then released water to form a hydroxyl methylene carbonium ion as shown in Scheme 2.
This ion acted as a hydroxy alkylating agent by reacting with a cardanol via electrophylic aromatic substitution. A pair of electrons from the benzene ring attacked electrophylic element forming an intermediate followed by deprotonation and regained the aromaticity of the ring. The reaction is shown in Scheme 3.

The methylol group of the hydroxy methylolated cardanol was unstable under acidic condition and might loose water readily to form a benzylic carbonium ion as shown in Scheme 4.

The products formed in Scheme 4 reacted with another cardanol molecule to form a methylene bridge in another electrophylic aromatic substitution. This process repeated until all formaldehyde was exhausted. The related reaction may be shown in Scheme 5 .

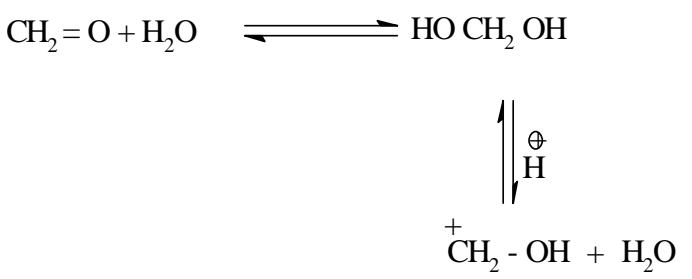

Scheme 2

\subsection{M olecular weight of cardanol-based novolac-type phenolic resin by gel permeation chromatographic (GPC) technique and mass spectroscopic analysis}

The average number molecular weight $\left(M_{n}\right)$ of $C F_{52}$ calculated from the number of phenolic units $(p)$ in the novolac resins (proposed structure in Scheme 6), which was determined from the ratio of aromatic-methylene 

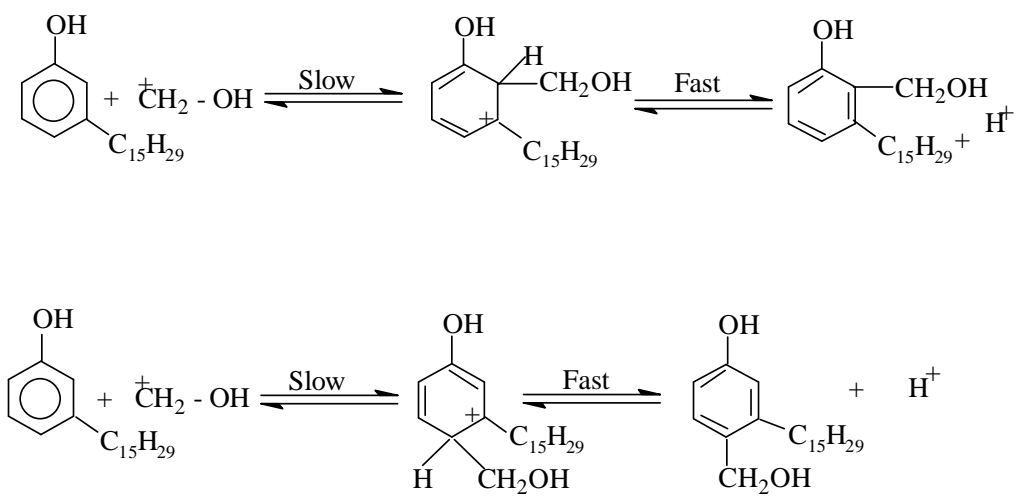

Scheme 3
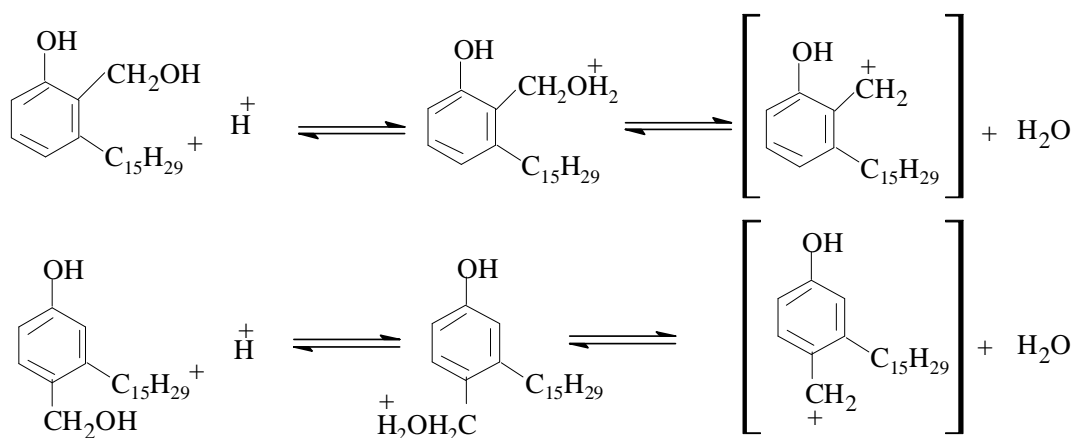

Scheme 4

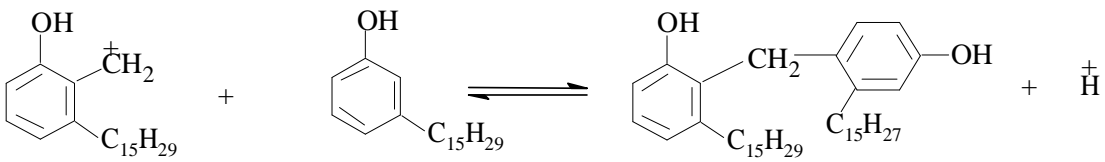<smiles>Oc1cccc(C(c2ccccc2)c2ccccc2)c1</smiles>

Scheme 5

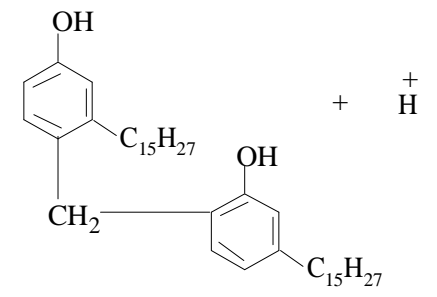

$\left[\mathrm{CH}_{2}\right]$ to aromatic protons, [AR], protons of the ${ }^{1} \mathrm{H}-\mathrm{NMR}$ spectra as the following equation [25]:

$$
\left[\mathrm{CH}_{2}\right] /[\mathrm{AR}]=(2 p-2) /(3 p+2)
$$

The calculated result was $M_{n}=670 \mathrm{~g} / \mathrm{mol}$ and $p=2.17$ for phenolic groups per molecule for a novolac resin $C F_{52}$. The value of molecular weight was further confirmed by GPC trace and mass spectroscopic analysis (Figs.3 and 4).

Finally, the structure of the cardanol-based novolac resins may be proposed as following:

\subsection{Epoxidation of novolac prepolymer}

The novolac based epoxy resin was synthesized by the reaction with epichlorohydrin $(E C H)$. The number of glycidyl groups per molecule in the resin depend upon the number of phenolic hydroxyls in the starting novolac, the extent to which they were reacted and the extent to which the lowest molecular species were polymerized during synthesis. Theoretically, all the phenolic hydroxyls might be reacted, but in practice all of them did not react because of steric hindrance [26]. The reaction between $E C H$ and novolac resin might be thought to proceed in a similar fashion as in the work given by Lee and Neville [26]. The epoxide group of $E C H$ reacted with phenolic hydroxyls under the alkaline medium and formed the chlorohydrin ether which underwent dehydrochlorination reaction and resulted in to glycidyl ether. The structure of the epoxy resin may be proposed as in Scheme 7. 

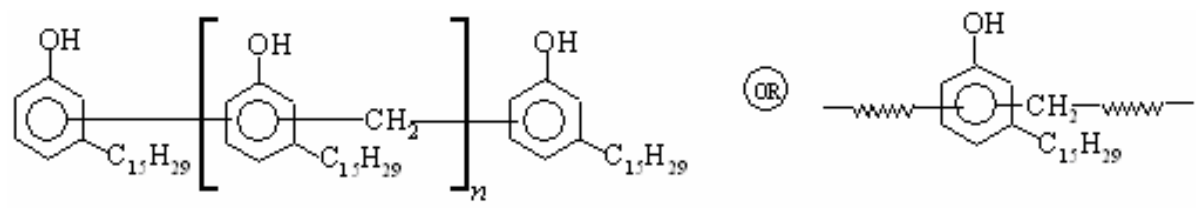

Scheme 6

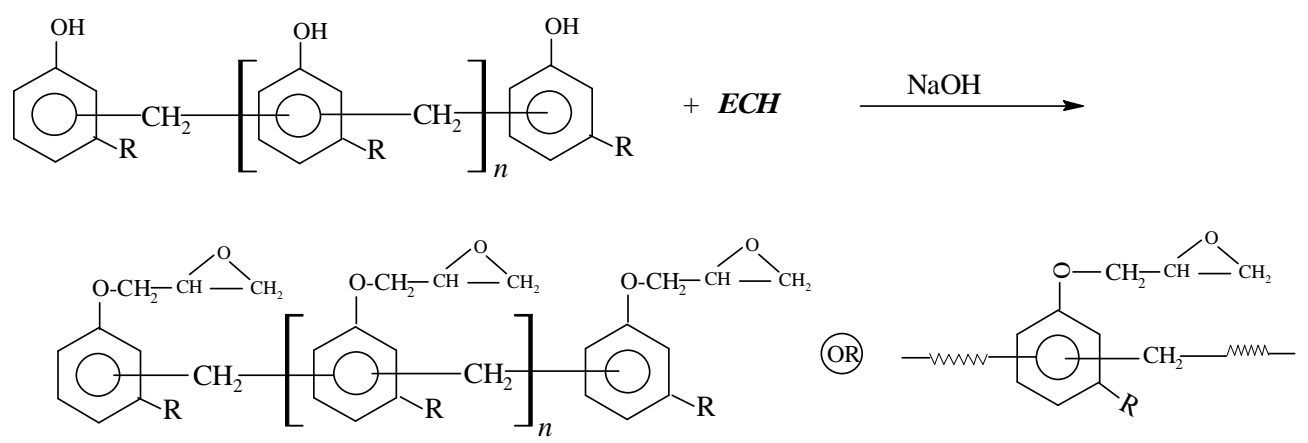

Where, $\mathrm{R}: \mathrm{C}_{15} \mathrm{H}_{29}$

Scheme 7

The FTIR spectra of uncured cardanol-based epoxidized novolac resins, i.e. sample $E C F_{52}$, the characteristic band of the oxirane ring was observed near 911 and $856 \mathrm{~cm}^{-1}$, as shown in Fig. 5. The ${ }^{1} \mathrm{H}-\mathrm{NMR}$ spectrum (Fig. 6) further confirmed the formation of cardanol-based epoxidized novolac resins. The epoxide equivalent weight of the prepared cardanol-based epoxidized novolac resins, i.e. sample $E C F_{52}$, was found to be $305 \mathrm{eq} / \mathrm{g}$, as determined by a titration method, whereas the molecular mass of the sample was $791 \mathrm{~g} / \mathrm{mol}$.

\subsection{FTIR analysis of uncured and cured blend samples}

FTIR spectral analysis of uncured blend sample containing $15 \mathrm{wt} \% \mathrm{CTBN}$ in epoxy resin $\left(E C F_{52}\right)$ is shown in Fig. 7. It is clear from the figure that the addition of CTBN into the neat epoxy resin shifted the peaks related to the oxirane functionality from 911 and $856 \mathrm{~cm}^{-1}$ (refer to Fig. 5) to 913 and $851 \mathrm{~cm}^{-1}$, respectively (Fig. 7). A minor change in the intensity of the peaks was also seen in the spectrum. These observations clearly indicated that there occurred a chemical reaction between a carboxyl group of CTBN and an epoxide group of the epoxy resin resulting in epoxy end-capped which would be capable of reacting with the hardener (refer to Fig. 8 for the FTIR spectrum of cured product) in the same way as diepoxy [27-28]. This was further confirmed by the appearance of a new stretching peak at $1492 \mathrm{~cm}^{-1}$ due to the formation of carboxylate anion and near $1737 \mathrm{~cm}^{-1}$ due to the formation of functional ester group and $\mathrm{C}-\mathrm{C}$ multiple bond stretching (Fig. 7).

\subsection{DSC analysis of blend samples}

Figs. 9 and 10 show the dynamic DSC scans of cardanol-based epoxidized novolac resins without and with CTBN (i.e. samples $E C F_{52}$ and $E C F_{523}$ ) at a heating rate of $283 \mathrm{~K} \mathrm{~min}^{-1}$. The effect of CTBN concentration on cure parameters of different epoxy matrices has also been compared to that of non-modified epoxy matrices in Table 2. It is evidenced from the results that the exotherm peak was shifted to lower temperatures due to enhanced reaction rate which, finally reduced the cure time of the CTBNmodified blend system (refer to Table 2). The initial addition of CTBN in the epoxy resin decreased the cure time sharply and this trend remained up to $15 \mathrm{wt} \%$ CTBN addition and increased thereafter. The enhanced rate behavior could be interpreted in terms of intermolecular transition state for the epoxy-amine reaction. According to this mechanism $[29,30]$ strong hydrogen bonding species, such as acids and alcohols, stabilized the transition state and strongly accelerated the curing reaction. The decrease of cure time could also be explained by the fact that during the reaction of CTBN with epoxy resin, some of the exothermic energy released during epoxy crosslinking it might have been consumed by CTBN resulting in decrease of cure time [31]. The $\Delta H$ values (Table 2) related to the cure process were determined from the area of the exotherm peak obtained from DSC analysis (Figs 9. and 10) taken in a dynamic mode. In contrast, the presence of CTBN did not affect significantly the heat of polymerization $(\Delta H)$, indicating insignificant influence on the crosslinking density of the epoxy matrix $[32,30]$. 


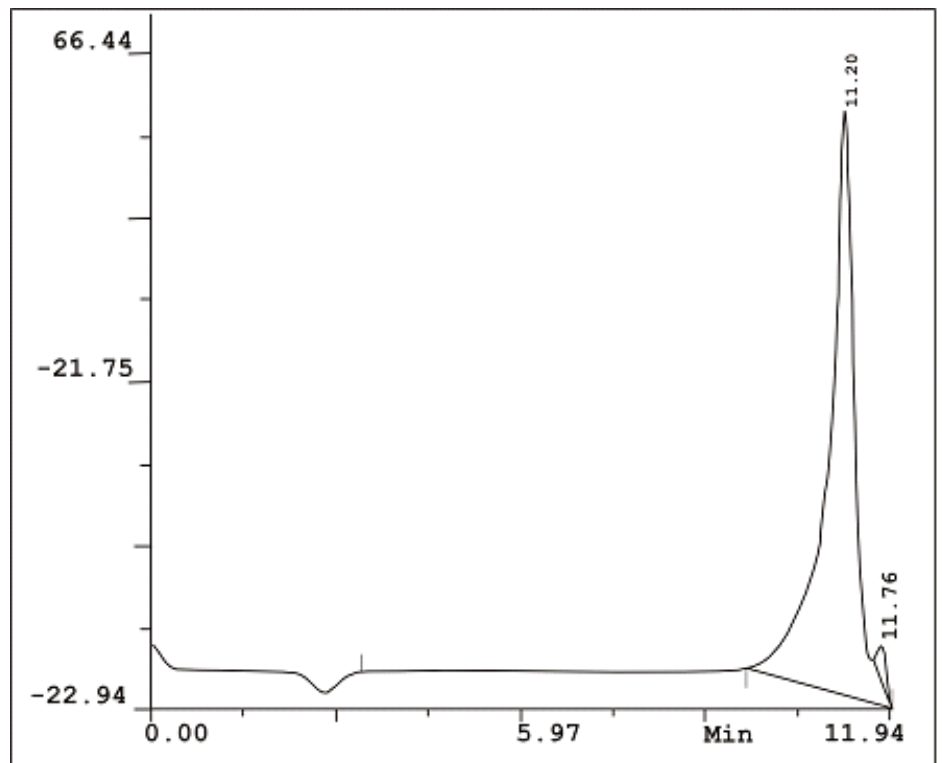

Fig. 3. GPC trace of novolac resin

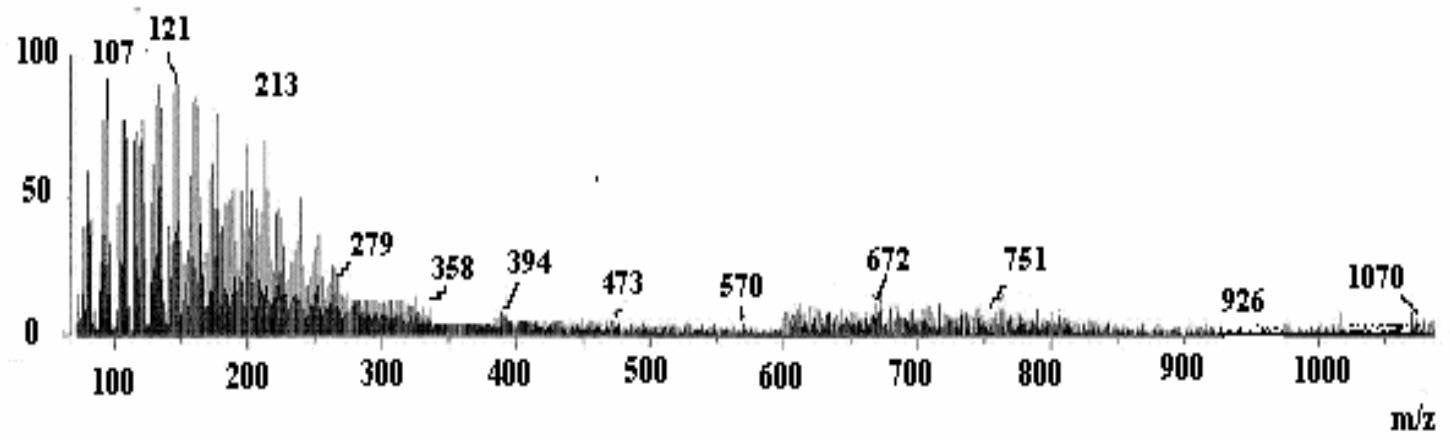

Fig. 4. MALDI-TOF mass spectrum of novolac resin $C F_{52}$

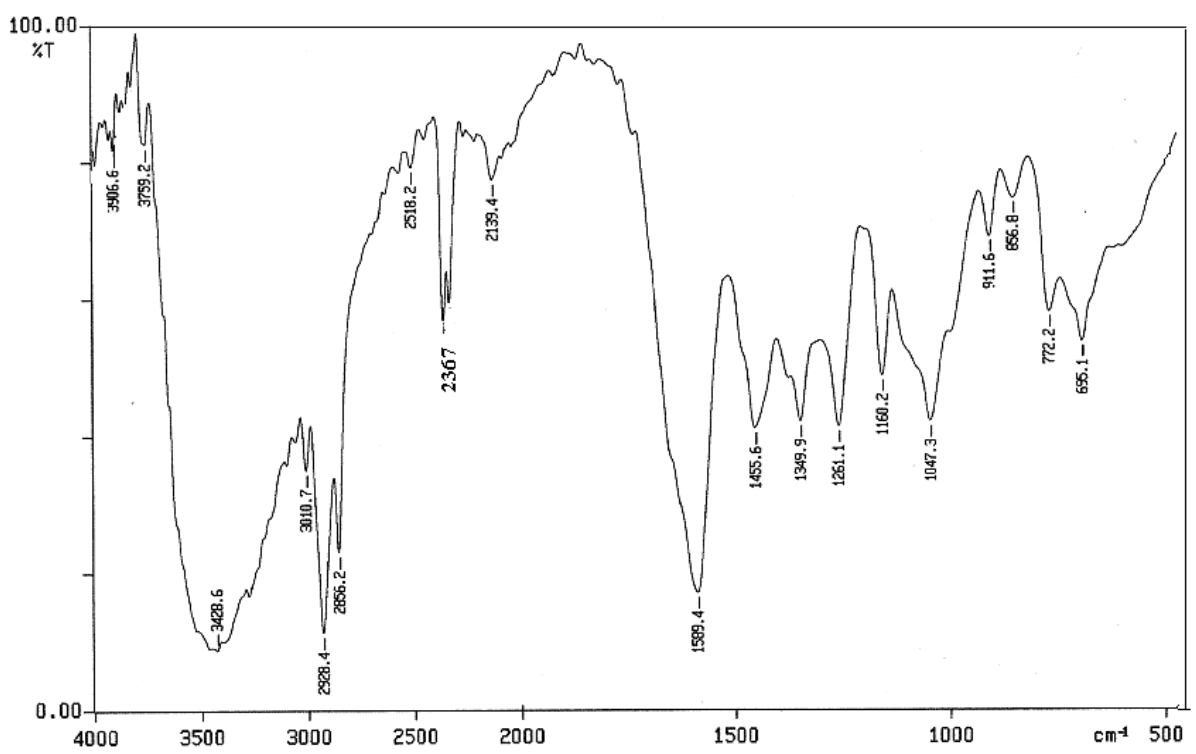

Fig. 5. FT-IR spectrum of epoxidized novolac resin $E C F_{52}$ 


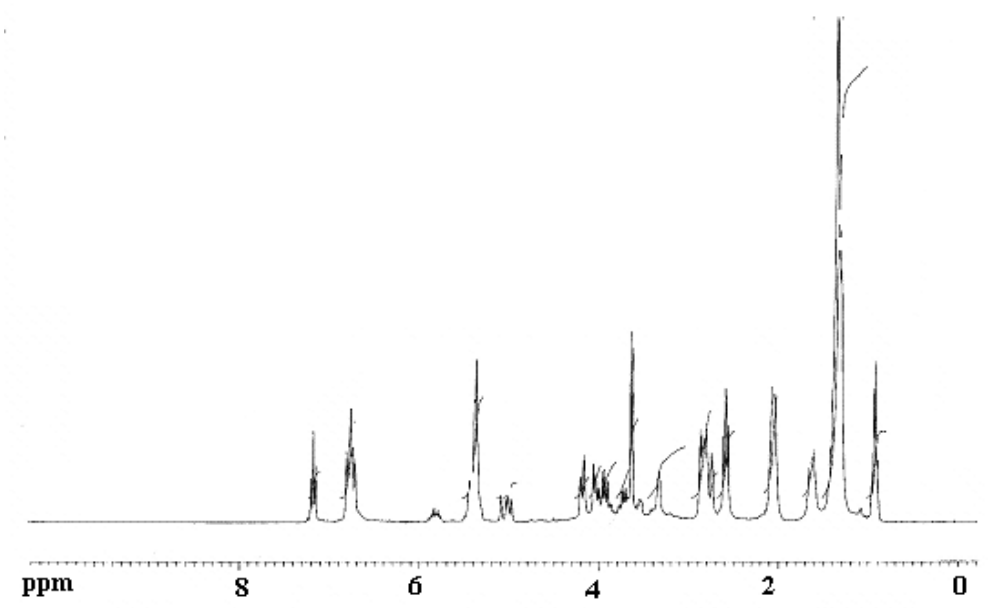

Fig. 6. ${ }^{1} \mathrm{H}-\mathrm{NMR}$ spectrum of epoxidized novolac resin $E C F_{52}$

DSC results of unmodified and CTBN-modified cardanol-based

Table 2 epoxidized novolac resin cured with polyamine

\begin{tabular}{|c|c|c|c|c|c|c|}
\hline Blend sample & $T_{i}, \mathrm{~K}$ & $T_{\text {onset }}, \mathrm{K}$ & $T_{P}, \mathrm{~K}$ & $T_{\text {stop }}, \mathrm{K}$ & $\Delta H, \mathrm{~J} \mathrm{~mol}^{-1}$ & ${ }^{a} t_{\text {cure }}, \mathrm{min}$ \\
\hline$E C F_{52}$ & 349.3 & 388.1 & 399.2 & 438.5 & 49.4 & 240 \\
\hline$E C F_{521}$ & 343.2 & 382.4 & 398.8 & 438.6 & 53.2 & 223 \\
\hline$E C F_{522}$ & 340.2 & 364.8 & 400.2 & 443.3 & 59.8 & 211 \\
\hline$E C F_{523}$ & 336.5 & 349.3 & 393.3 & 436.0 & 62.9 & 180 \\
\hline$E C F_{524}$ & 341.6 & 371.5 & 396.6 & 442.8 & 58.4 & 191 \\
\hline
\end{tabular}

${ }^{a}$ Cure time obtained by curing the sample in air oven at $393 \mathrm{~K}$.

$T_{i}$ - kick-off temperature, where the curing starts; $T_{\text {onset }}$ - temperature where the first detectable heat is released; $T_{P}-$ temperature of peak position of exotherm; $T_{\text {stop }}$ - temperature of end of curing exotherm; $\Delta H$ - heat of curing; $t_{\min }$ - cure time in minutes.

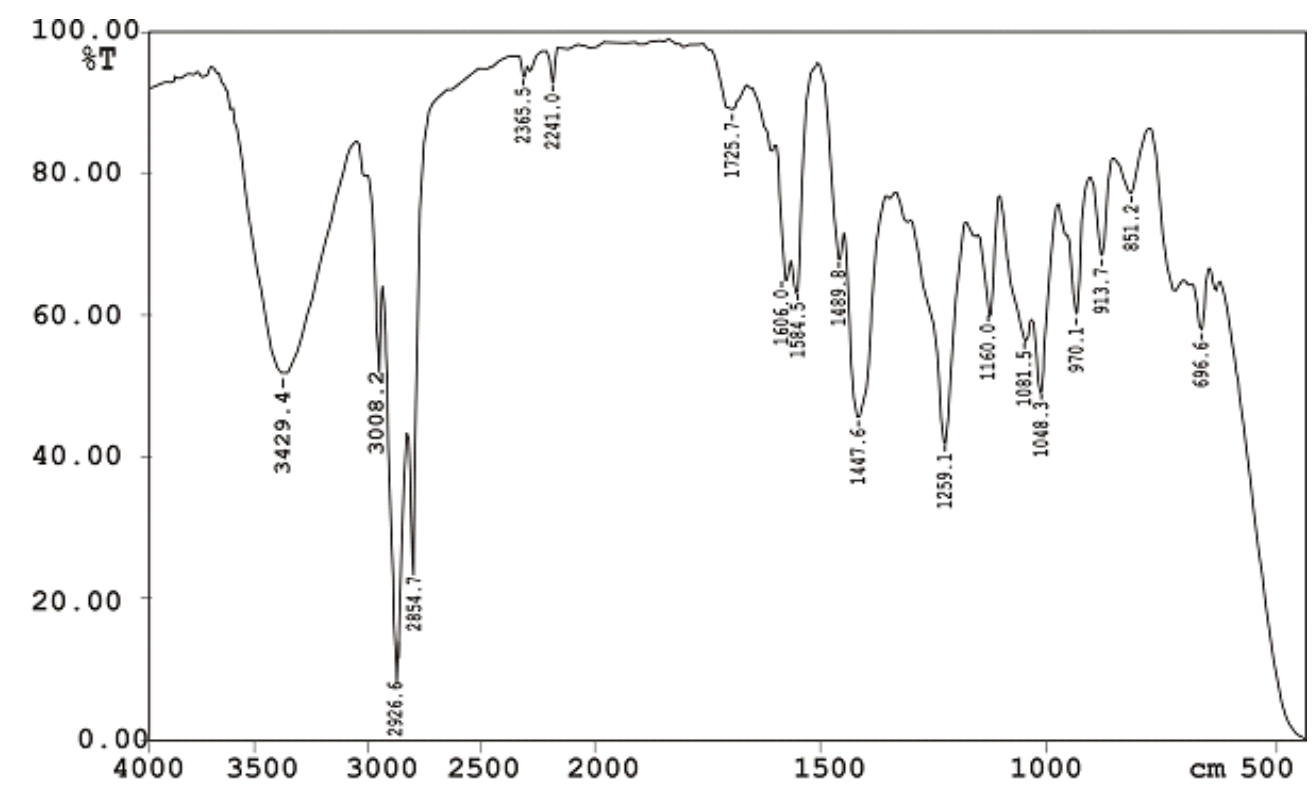

Fig. 7. FTIR spectrum of uncured blend sample $B E C F_{523}$ 


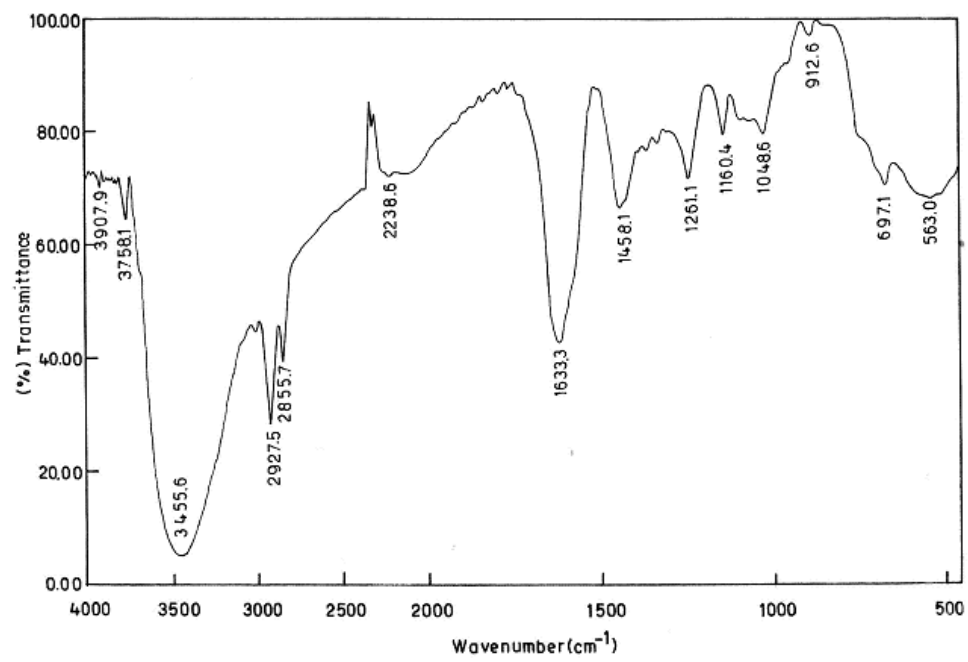

Fig. 8. FTIR of cured blend sample $B E C F_{523}$

Table 3

Results of TG/DTG traces of unmodified and CTBN-modified cardanol-based epoxidized novolac resins cured with polyamine

\begin{tabular}{|c|c|c|c|c|c|c|c|c|c|}
\hline \multirow{2}{*}{$\begin{array}{c}\text { Blend } \\
\text { sample }\end{array}$} & \multicolumn{4}{|c|}{ First step } & \multicolumn{4}{c|}{ Second step } & Total \% CY \\
\cline { 2 - 10 } & $T_{o}$ & $T_{\max }$ & $T_{f}$ & $\% C Y$ & $T_{o}$ & $T_{\max }$ & $T_{f}$ & $\% C Y$ & \\
\hline$E C F_{52}$ & 465 & 589 & 616 & 49.3 & 616 & 711 & 771 & 47.2 & 3.5 \\
\hline$E C F_{521}$ & 451 & 592 & 626 & 62.6 & 626 & 702 & 787 & 34.4 & 3.2 \\
\hline$E C F_{522}$ & 441 & 599 & 630 & 90.7 & 630 & 713 & 772 & 7.0 & 2.3 \\
\hline$E C F_{523}$ & 449 & 578 & 628 & 53.8 & 628 & 711 & 764 & 42.1 & 4.1 \\
\hline$E C F_{524}$ & 472 & 595 & 628 & 55.6 & 628 & 714 & 778 & 40.5 & 3.9 \\
\hline
\end{tabular}

Note: $T_{o}$ - onset temperature of degradation; $T_{\max }$ - temperature of maximum rate of mass loss; $T_{f}$ - extrapolated final decomposition temperature; $C Y$ - char yield.

\subsection{Thermal stability}

The systems were evaluated for the thermal stability in nitrogen atmosphere by thermogravimetric analysis. The thermogravimetric results (TG) obtained for samples $E C F_{52}$ and $E C F_{523}$ are shown in Figs. 11 and 12 for the evaluation of thermal stability in the nitrogen atmosphere. The onset temperature of degradation $\left(T_{o}\right)$, temperature of maximum rate of mass loss $\left(T_{\max }\right)$ and extrapolated final decomposition temperature $\left(T_{p}\right)$ were noted from TG traces and are presented in Table 3. TG analysis confirmed the occurrence of samples degradation. The degradation of the blend systems was found to occur in two steps. The temperature of $5 \%$ weight loss increased slightly from $567 \mathrm{~K}$ for pure epoxy (sample $E C F_{52}$ ) resin to $573 \mathrm{~K}$ for the epoxy/CTBN blend (i.e. blend sample $E C F_{523}$ ). The addition of the appropriate amount of epoxy could decrease the mobility and increase the stability of CTBN via the reaction between the thermal carboxyl group of CTBN and hydroxyl group of epoxy [33-36].

\subsection{Scanning electron microscopic analysis}

Figs.13 and 14 show the SEM micrographs of fractured surface of the pure epoxy and CTBN modified epoxy matrix respectively. SEM of CTBN modified system showed the presence of precipitated, discrete rubber particles, which were dispersed throughout the epoxy matrix, i.e. they revealed the presence of two-phase morphological features. The soft elastomeric phase was separated from the hard epoxy matrix during the early stage of the cure. The fractured surface of the most of the rubber-toughened epoxy system has a rigid continuous epoxy matrix with a dispersed rubbery phase as isolated particles [37]. Some cavitations of the rubber particles accompanied by stress whitening zones were also observed in the scan (Fig.14). This stress whitening effect may be related to the location deformation at the crack tip. Furthermore, the cavitations were followed by the onset of the shear localization process [38-40] resulting in the observed increase of thermal properties.

\section{Conclusions}

DSC studies showed the exothermal heat of epoxy crosslinking reaction due to addition of rubber into epoxy 
Ranjana Yadav et al.

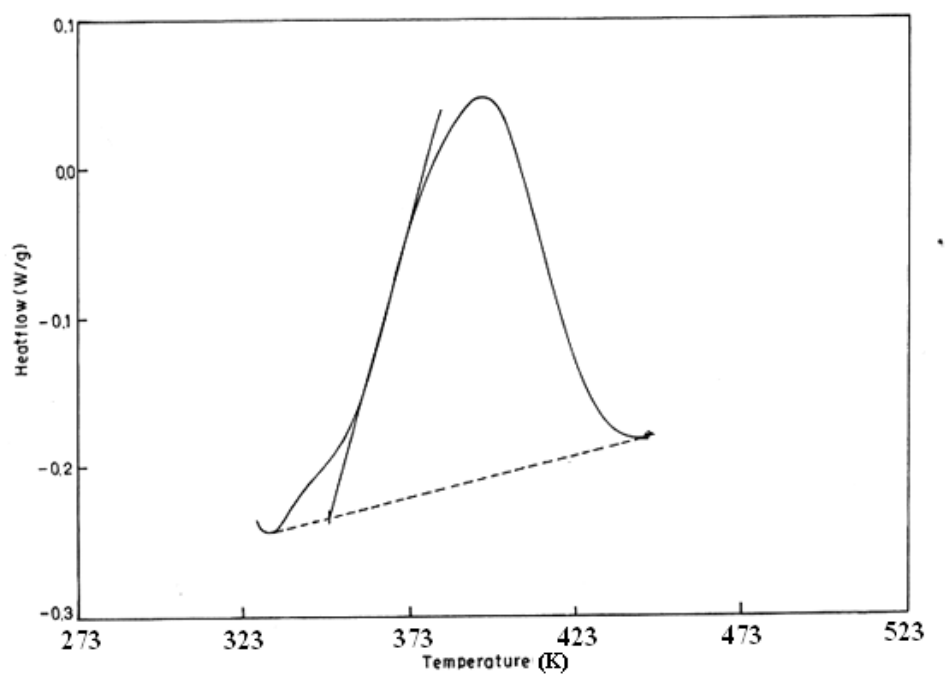

Fig. 9. DSC scan of epoxidized novolac resin $E C F_{52}$.

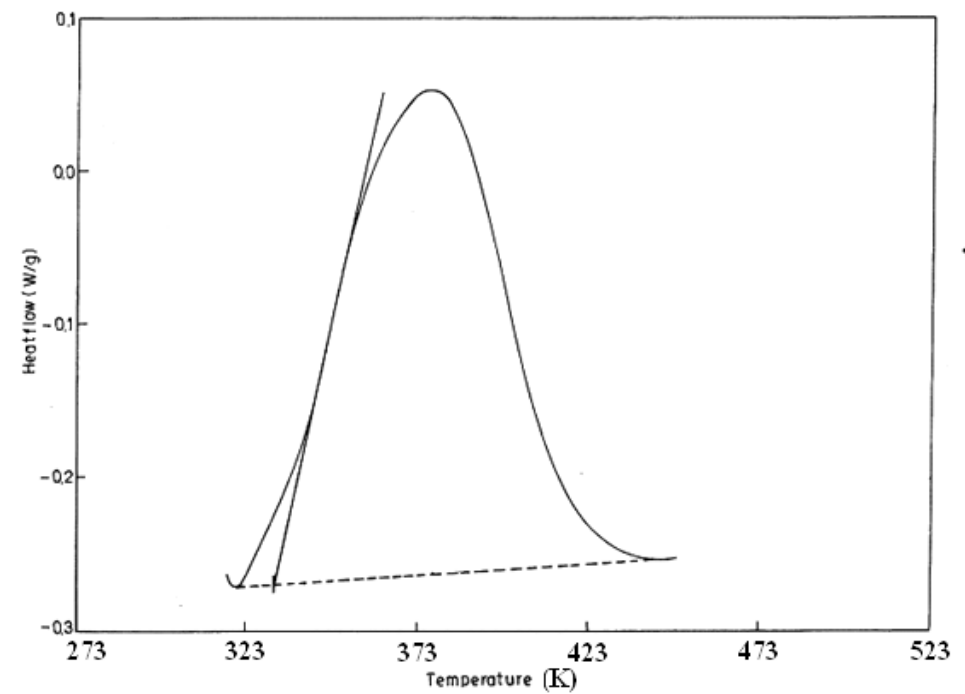

Fig. 10. DSC scan of blend sample $\mathrm{BECF}_{523}$

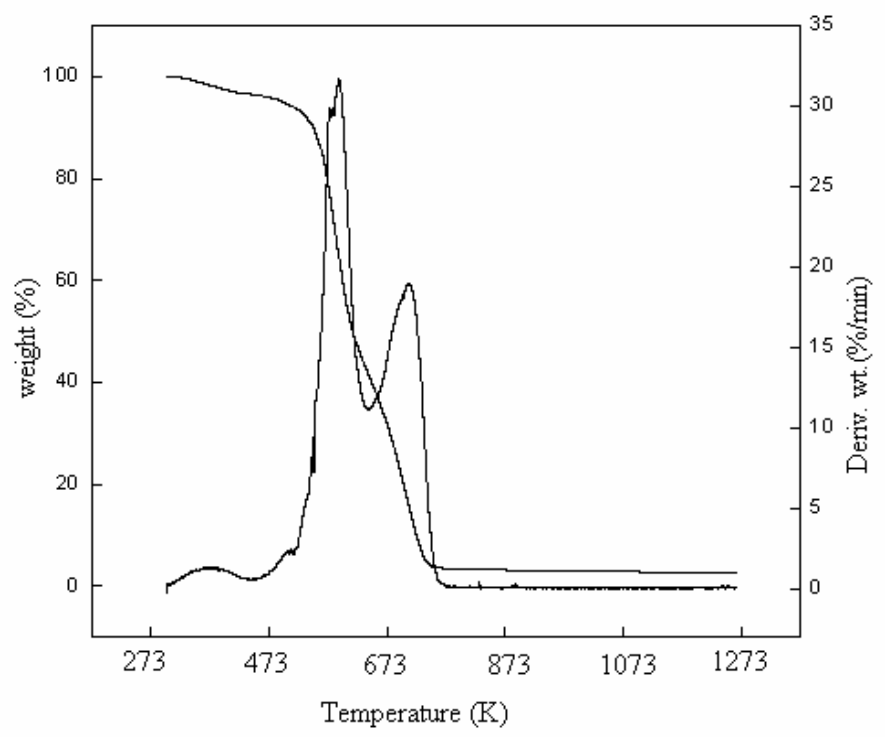

Fig. 11. TGA Trace of blend sample $E C F_{52}$ 


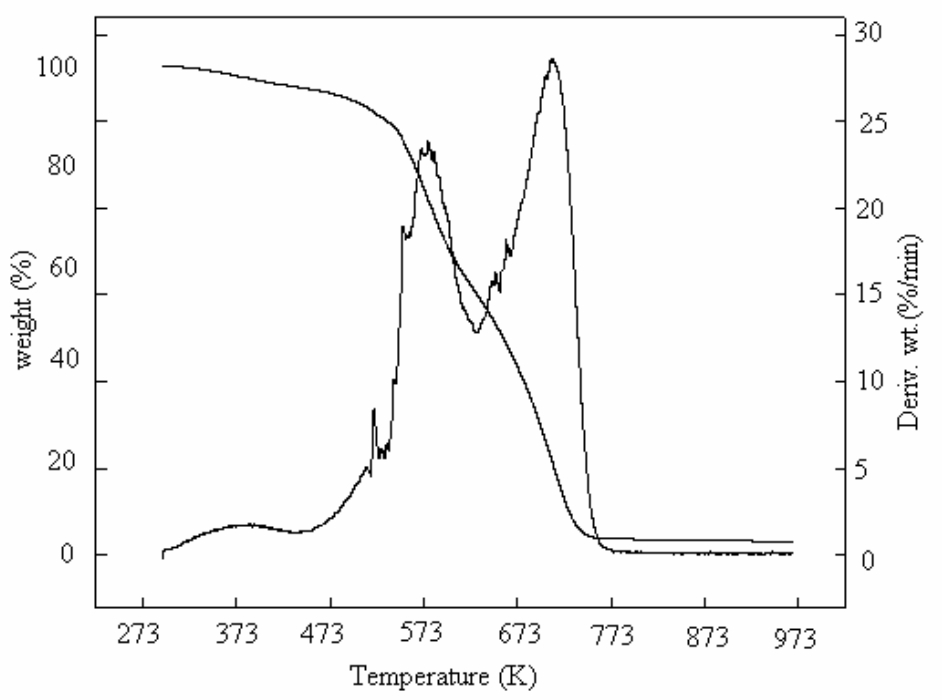

Fig. 12. TGA Trace of blend sample $B E C F_{523}$

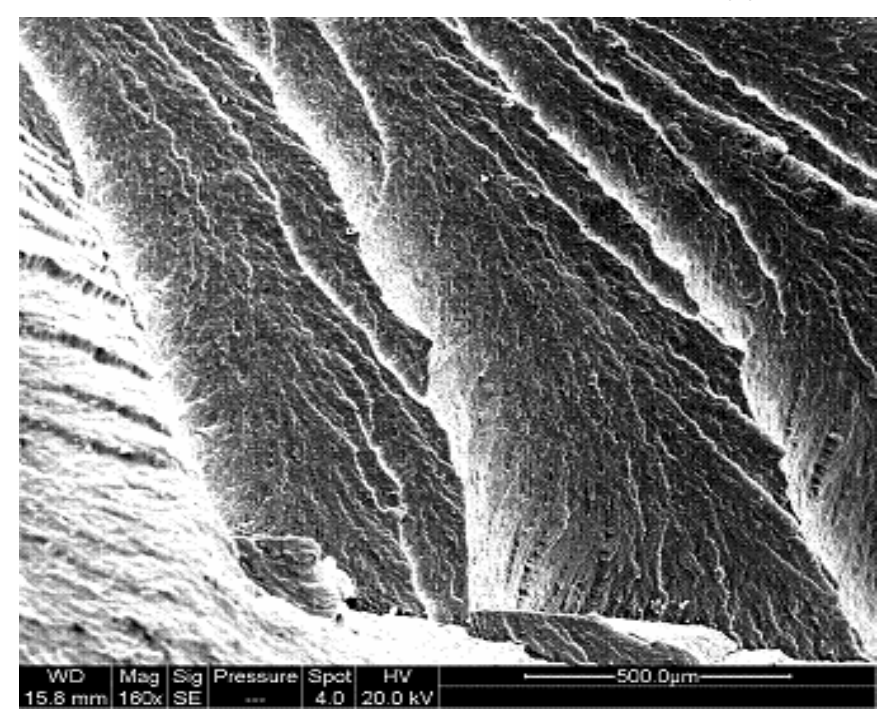

Fig. 13. SEM micrographs of preapared sample $E C F_{52}$

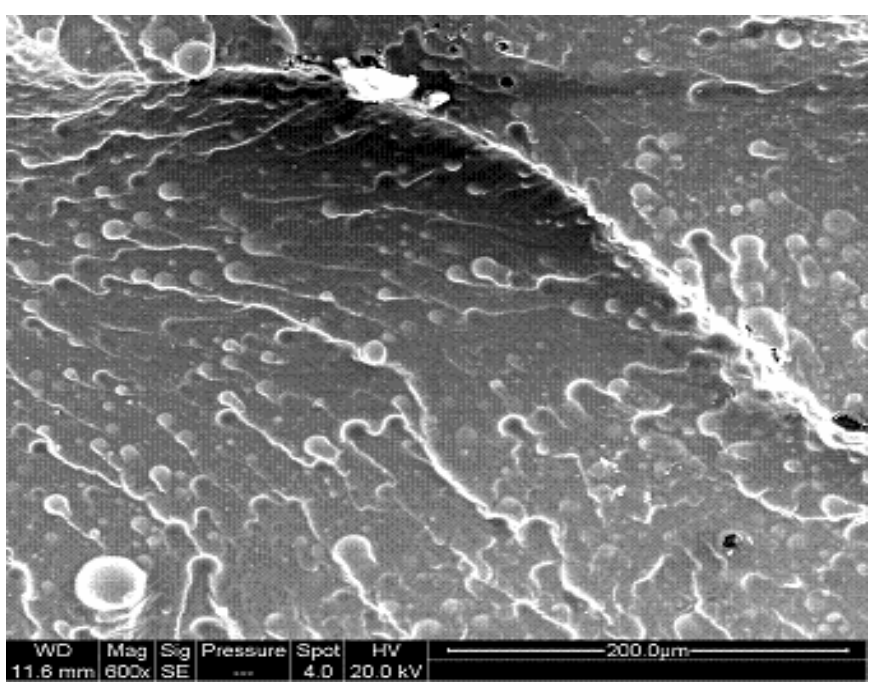

Fig. 14. SEM micrographs of preapared sample $B E C F_{523}$ 
matrix. The thermal stability of the cardanol based epoxy resin was increased with the addition of $15 \mathrm{wt} \%$ CTBN in the epoxy matrix. Cardanol-based epoxy network modified with CTBN displayed two phase separated morphology with dispersed rubber globules in the matrix resin.

\section{Acknowledgements}

This work was sponsored by Council of Science and Technology, UP, Lucknow. We, also, thankfully acknowledge the contributions rendered by M/s Satya Cashew Pvt. Ltd., Chennai for providing cardanol and M/ s Emerald Performance Materials, LLC, Hong Kong for providing CTBN.

\section{References}

[1] Attanasi O. and Bunatti S.: La Chimica e I'Industria, 1996, 78, 693.

[2] Prabhakaran K., Narayan A. and Pvithram C.: Eur. Cer. Soc., 2001, 21, 2873.

[3] Pillai C., Prasad V., Sudha J., Bera S. and Menon A.: J. Appl. Polym. Sci., 1990, 41, 2487.

[4] Bhunia H., Nando G., Chakib T. et al..: Euro. Polym. J., 1999, 35, 1381.

[5] Kinloch A. and Reiw C.: Rubber-Toughened Plastics Advances in Chemistry, Am. Chem. Soc., Ser 22:67, Washington DC 1989.

[6] Kinloch A. and Young R.: Fracture behaviour of polymers, Appl. Sci., London 1983.

[7] Huang J. and Kinloch A.: Polymer, 1992, 33, 1330.

[8] Huang J. and Kinloch A.: J. Mater. Sci., 1992, 27, 2763.

[9] Riew C., Rowe E. and Siebert A.: Rubber toughened thermosets: ACS meeting- symposium on toughness and brittleness of plastics, division of organic coatings and plastics Attantic city, N.J, October 18, 1974.

[10] Frigone M., Masica L. and Aciermo D.: Eur. Polym. J., 1995, 31, 1021.

[11] Tripathi G. and Srivastava D.: Mat. Sci. Eng:A, 2007, 443, 262.

[12] Pearson R. and Yee A.: J. Mater. Sci., 1989, 24, 2571.

[13] Clayton May: Epoxy resin - Chemistry and technology, Marcel Dekker, New York 1988.

[14] Knop A. and Schieb W.: Chemistry and application of phenolic resins, Springer Verlag, New York 1979.

[15] Devi A., Chandra K. and Srivastaava D.: Proceedings of the $14^{\text {th }}$ National Thermal Analysis Symposium, Vadodra, India, 2004, 22.

[16] Devi A. and Srivastava D.: Mater. Sci. Eng. A, 2007, 458, 336. [17] Urabanski J., Czer Winkski W., Janika K, Majewsta F. and Zowall H.: Handbook of analysis of synthetic polymers and plastics, Ellis Horward ltd., Chicketa 1977.

[18] Sperling G.: J. Am. Chem. Soc., 1954, 76, 1190.

[19] Sathiyalekshmi K.: Bull. Mater. Sci., 1993, 16, 137.

[20] Chakrawarti P. and Mehta V.: Ind. J. Tech., 1987, 25, 109.

[21] Mythili C., Retna A. and Gopalkrishnan S.: Bull. Mater. Sci., 2004, 27, 235.

[22] Tyman J.: Chem. Soc. Rev., 1979, 8, 499.
[23] Huang J., Xu M., Lin M., Lin Q., et al.: J. Appl. Polym. Sci., 2005, 97, 652.

[24] Kuriaposa A. and Manjooran S.: Surf. Coat. Tech., 2001, $145,132$.

[25] Lin-Gibson S., Baranauskas V., Riffle J.S. and Sorathia V.: Polymer, 2000, 43, 7389.

[26] Lee H. and Neville K.: Hand book of epoxy resins, McGraw-Hill, New York 1982.

[27] Evtushenko Yu., Ivanov V. and Zaitsev B.: J. Anal. Chem., 2003, 58, 347.

[28] Smith A.: Applied infrared spectroscopy, Wiley, NewYork 1979.

[29] Horie K., Hiura H., Sawada M., Mita I. and Kambe H.: J. Polym. Sci. A-1, 1970, 8, 1357.

[30] Ruzenberg B.: Adv. Polym. Sci., 1985, 75, 113.

[31] Wise C., Cook W. and Goodwin A.: Polymer, 2000, 41, 4625 .

[32] Calabrese L. and Valenza A.: Comp. Sci. Tech., 2003, 63, 851. [33] Cataloni A. and Bonicelli M.: Thermochimica Acta, 2005, 438, 126.

[34] Gu A. and Liang G.: J. Appl. Polym. Sci., 2003, 89, 359.

[35] Maity T., Samanta B., Dalai S. and Banthia A.: Mat. Sci. Eng: A, 2007, 464, 38.

[36] Kaji M., Nakahara K. and Endo T.: J. Appl. Polym. Sci., 1999, 74, 690 .

[37] Sulton J. and Garry Mc: J. Polym. Eng. Sci., 1973, 13, 29. [38] Verchere D., Sautereau H. and Pasculat J.: J. Appl. Polym. Sci., 1990, 41, 467.

[39] Chan L., Gillham J., Kinloch A. and Shaw S.: [in:] Riew C. and Gillham J. (eds.), Rubber-modified epoxies: morphology, transitions and mechanical properties. American Chemical Society, Washington D.C 1984, v. ACS 208.

[40] Sue H., Garciameitin E. and Pickelman D.: [in:] Arands C. (Ed.) Polymer toughening. Marcel Dekker, NewYork 1996.

\section{ВИВЧЕННЯ ЕПОКСИДНИХ НОВОЛАЧНИХ СМОЛ НА ОСНОВІ КАРДАНОЛУ ТА ЇХ СУМІШЕЙ}

Анотація. Синтезовано фенольну новолачну смолу на основі карданолу з мольним співвідношенням карданол:формальдегід 1.0:0,5 з використанням як каталізатор дикарбонової кислоти, зокрема янтарної. Таку смолу у подальшому модифікували надлишком епіхлоргідрином при 393 К у лужному середовищі. Вивчені у різному масовому співвідношенні суміші дигліщиділового етеру бісфенолу $A$ i поліглічидної новолачної смоли з кополімером бутадієну з акрилонітрилом, що містить кінцеві карбоксильні групи (БАКК). Як структуруючий агент таких сумішей використаний поліамін у стехіометричній кількості стосовно епоксидних груп. Формування зщитих структур вищеназваних сумішей вивчено різними методами ІЧ-спектроскопічного аналізу. . Середньомолекулярну масу визначали гель-хроматографією. Встановлено, що мінімальна тривалість структурування $i$ найвища термічна стабільність систем спостерігається при вмісті в таких сумішах $15 \%$ мас. БАКК.

Ключові слова: карданол, формальдегід, новолак, епіхлоргідрин, епоксидна смола, бутадієн-акрилонітриловий кополімер, спектральні методи. 